\title{
Using Traditional Knowledge to Adapt to Ecological Change: Denésołıné Monitoring of Caribou Movements
}

\author{
BRENDA PARLEE,,$^{1,2}$ MICHELINE MANSEAU ${ }^{1,3}$ and LUTSËL K’É DENE FIRST NATION ${ }^{4}$
}

\author{
(Received 25 February 2003; accepted in revised form 14 June 2004)
}

\begin{abstract}
The Chipewyan Dene or Denésołıné have long been dealing with variability in the movements of barren-ground caribou (Rangifer tarandus). Many generations ago, Denésołıné hunters learned that by observing caribou at key water crossings during the fall migration, they could obtain critical information about caribou health, population, and movement patterns. Systematic observation of these indicators by hunters strategically organized along the tree line enabled the Denésołıné to adapt their harvesting practices, including the location of family camps, to maximize harvest success. While this system of observation was developed for traditional subsistence harvesting, its techniques could be usefully applied today to other natural resource management contexts. In particular, such monitoring might help us understand how new bifurcation points created by mineral resource development may be affecting the Bathurst caribou herd. As governments, communities, and academics search for ways to include traditional knowledge in decision making for resource management, this paper recognizes that the Denésołıné and other indigenous peoples have their own systems of watching, listening, learning, understanding, and adapting to ecological change.
\end{abstract}

Key words: caribou, fall migration, hunting, harvesting, monitoring, traditional ecological knowledge, Dene, Denésǫłıné, unpredictability, diamond mining, environmental impacts

RÉSUMÉ. Les Dénés Chipewyans ou Denésǫłné ont eu depuis longtemps à faire face à la variabilité dans les déplacements du caribou de la toundra (Rangifer tarandus). Il y a de cela des générations, les chasseurs Denésołıné ont appris qu'en observant le caribou aux traversées majeures de cours d'eau durant la migration automnale, ils obtenaient de l'information critique sur la santé et la population de caribou, ainsi que sur ses habitudes migratoires. L'observation systématique de ces indicateurs par des chasseurs placés de façon stratégique le long de la ligne des arbres permettait aux Denésołıné d'adapter leurs pratiques de prélèvement, y compris l'emplacement des camps pour leur famille, afin d'optimiser le succès de la récolte. Si ce système d'observation a été mis au point pour la récolte de subsistance traditionnelle, ses techniques pourraient s'avérer utiles de nos jours pour d'autres contextes de gestion des ressources naturelles. Un tel suivi pourrait en particulier nous aider à comprendre comment de nouveaux points de bifurcation créés par l'exploitation des ressources minérales pourraient influer sur la harde de caribous de Bathurst. Au moment où gouvernements, collectivités et chercheurs sont en quête de modalités permettant d'inclure le savoir traditionnel dans la prise de décisions visant la gestion des ressources, cet article reconnaît que les Denésołłné et autres peuples autochtones ont leurs propres systèmes d'observation, d'écoute, d'apprentissage, de compréhension et d'adaptation aux changements écologiques.

Mots clés: caribou, migration automnale, chasse, prélèvement, surveillance, savoir écologique traditionnel, Déné, Denésołıné, imprévisibilité, exploitation de mines de diamants, impacts environnementaux

Traduit pour la revue Arctic par Nésida Loyer.

\section{INTRODUCTION}

The traditional ecological knowledge and management practices of indigenous peoples can provide tremendous insight into how to deal with ecological uncertainty (Berkes et al., 2003). Monitoring is among those practices recognized as crucial to ensuring the long-term sustainability of natural ecosystems and the communities that depend on them to survive (Berkes et al., 2000; Parlee et al., 2005).
This paper describes a system of monitoring based on traditional ecological knowledge that enabled the Chipewyan Dene or Denésołıné to learn and adapt to variability in the fall movements of barren-ground caribou (Rangifer tarandus).

During fall migration, the Bathurst, Beverly, and Ahiak caribou herds travel from their calving grounds at Bathurst Inlet, Beverly Lake, and the Queen Maud Gulf near the Arctic coast to their fall and wintering grounds near the

\footnotetext{
${ }^{1}$ Natural Resources Institute, 70 Dysart Rd., University of Manitoba, Winnipeg, Manitoba R3T 3C1, Canada

${ }^{2}$ Corresponding author: parleeb@shaw.ca

${ }^{3}$ Western Canada Service Centre, Parks Canada, 145 McDermot Ave., Winnipeg, Manitoba R3B 0R9, Canada;

Micheline.Manseau@pc.gc.ca

${ }^{4}$ Wildlife, Lands and Environment Committee Office, Box 28, Lutsël K’é, Northwest Territories X0E 1AO, Canada; wildlife@lutselke.com

(C) The Arctic Institute of North America
} 


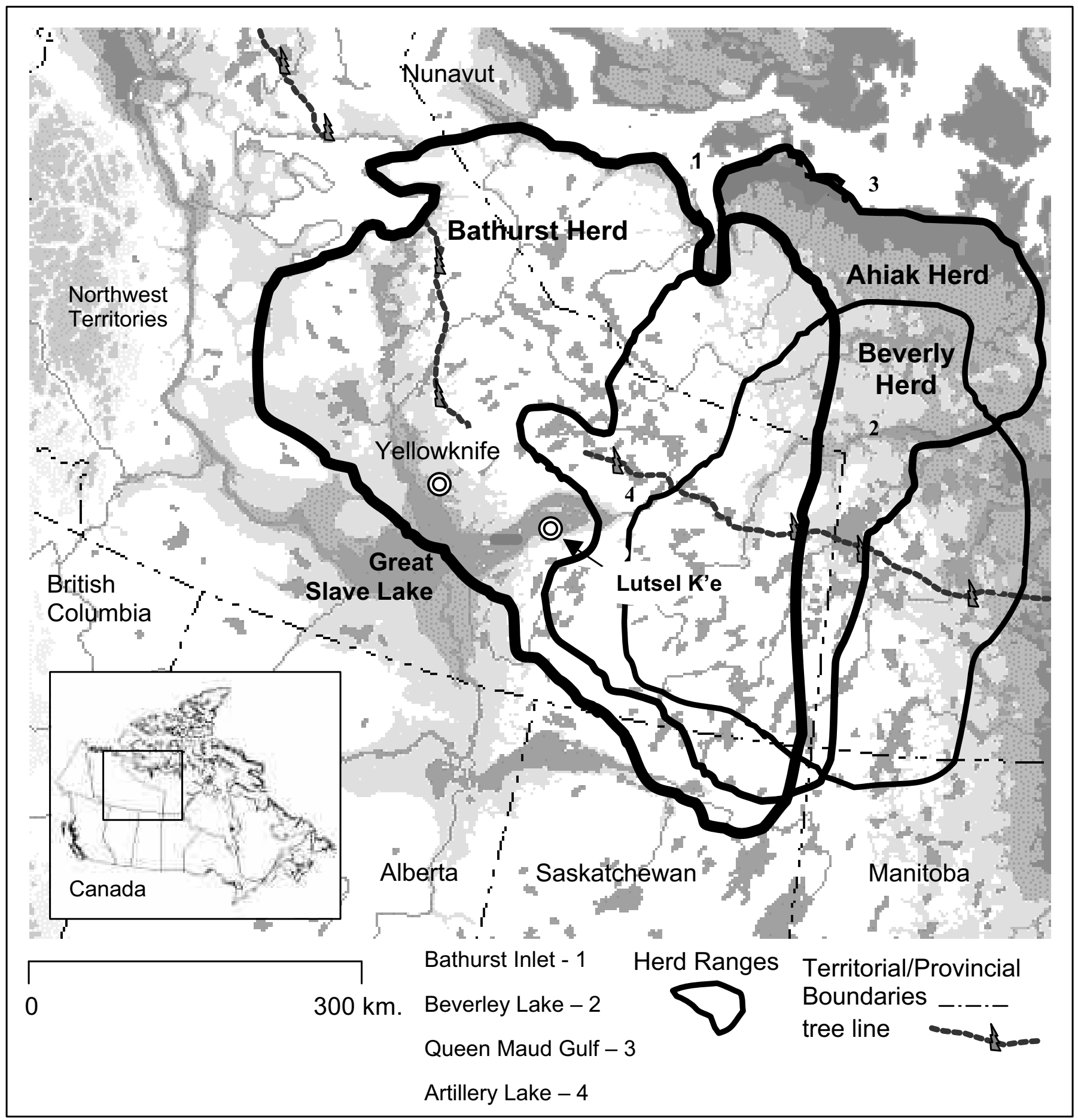

FIG. 1. Study area: Łutsël K'é within the Bathurst, Beverly and Ahiak caribou ranges (map adapted from Resources, Wildlife and Economic Development, 2004).

tree line (Fig. 1). Although each herd occupies a defined range over time (Resources, Wildlife and Economic Development, 2004), the distribution of the three herds across those ranges can vary significantly from year to year (Gunn et al., 2001). In a given fall, large numbers of caribou may cluster around Artillery Lake $\left(63^{\circ} 13^{\prime} \mathrm{N}\right.$, $108^{\circ} 04^{\prime} \mathrm{W}$ ) or areas west of Yellowknife-a span of over $500 \mathrm{~km}$ (Fig. 1). In addition, the timing of migration or the presence of caribou at a given location on the landscape also varies between years. This spatial and temporal variability of caribou distribution on the landscape is well understood by the Dene communities that depend on caribou to survive (Dogrib Treaty 11 Council, 2001; Parlee et al., 2001).

Different hypotheses have been proposed to explain the interannual variability of caribou movements and range use, including availability of food sources, weather, parasites, and predators (Messier et al., 1988; Manseau et al., 


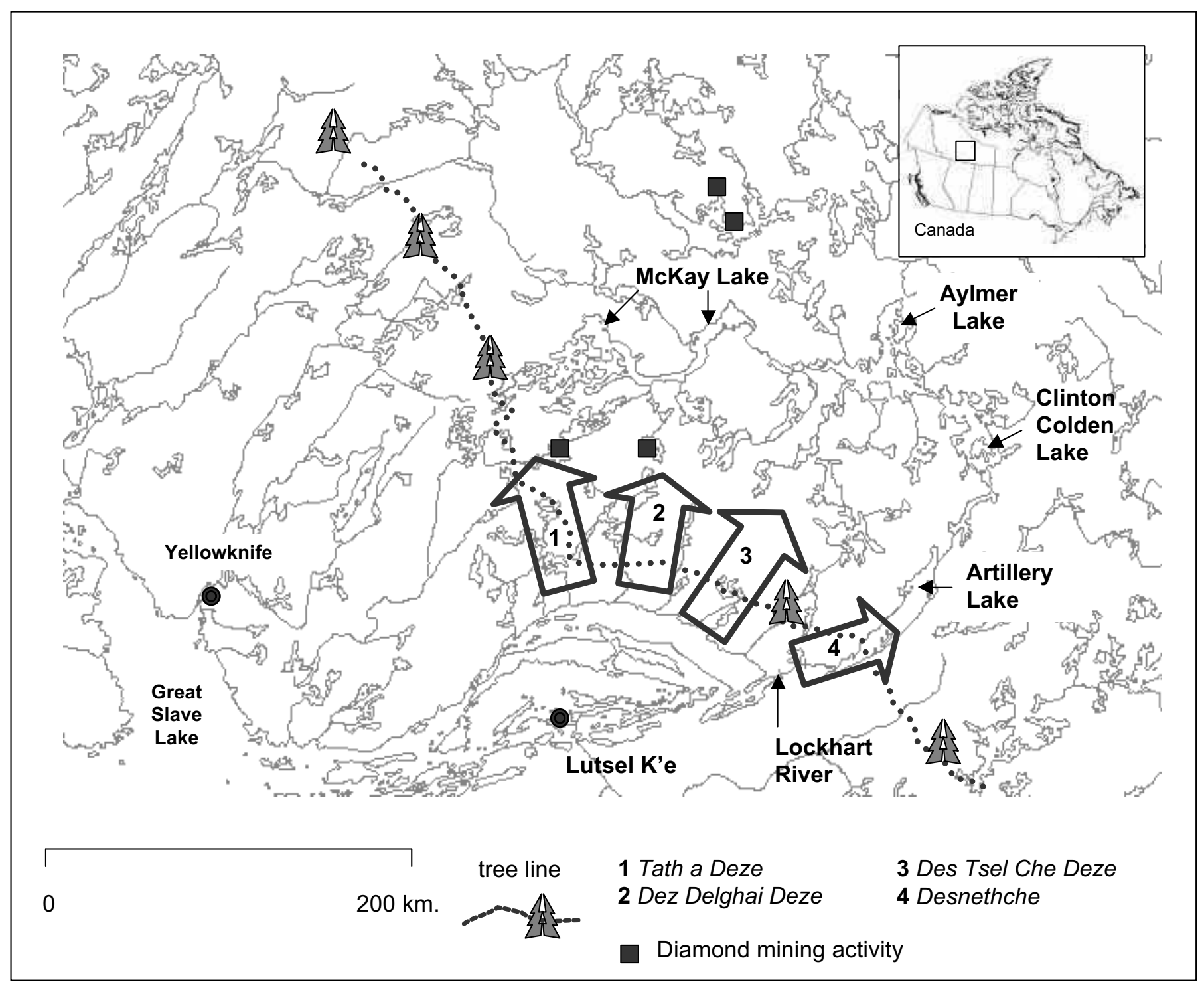

FIG. 2. Denésołıné travel routes into the Barren Lands.

1996; Fryxell and Sinclair, 1998; Dogrib Treaty 11 Council, 2001; Gunn et al., 2001). There is, however, little capacity to predict seasonal movements and range use from such factors (Gunn et al., 2001). Predicting movements becomes even more complicated in the face of human disturbances, particularly linear disturbances. Studies done around Prudhoe Bay, Alaska, provide some evidence that roads and other linear developments are affecting caribou movements during spring migration (Cameron et al., 1992, 1995; Wolfe et al., 2000); however, a direct cause-and-effect relationship has not been established.

This paper on the Denésołıné monitoring of caribou movements builds on previous research on Dene harvesting and social organization (Irimoto, 1981; Jarvenpa and Brumbach, 1988) and, most specifically, on Dene hunting strategies (Smith, 1978). Smith argued that the social network of central Arctic Dene groups, which were "strategically situated in a long narrow front near the tree line, from a point west of Hudson's Bay to Great Slave Lake" (1978:78), provided for significant adaptation to caribou movements (Fig. 2). This paper describes how the Denésołıné, strategically organized along the tree line, learned about and adapted to caribou movements by systematically observing and communicating about movements at water crossings known to be bifurcation points.

\section{STUDY AREA: THE DENÉSQŁINÉ AND THE BARREN-GROUND CARIBOU}

Lutsël K'é, formerly called Snowdrift, is a community of 350 Chipewyan Dene located on the east arm of Great Slave Lake in the Northwest Territories (Fig. 1). Traditionally, the Denésołıné of Łutsël K'é did not inhabit a single settlement; like many other Dene in the region, they were organized in local and regional family groups (bands) 
across a vast expanse of present-day Northwest Territories and northern Saskatchewan (Smith, 1976, 1978). Described as the most widely traveled and most numerous of the Northern Athapaskans, they occupied "the forest-tundra ecozone (the 'edge of the forest') near Hudson's Bay, north of the Seal River, in a wide northwesterly arc to north of the Arctic Circle" (Smith, 1981:271).

The area of the Denésołıné traditional territory described in this paper stretches across the fall and winter ranges of the Bathurst, Beverly, and Ahiak caribou herds (Fig. 1). Traditional knowledge and archaeological evidence suggest that people have been hunting caribou in this area for thousands of years (Noble, 1971; Łutsël K'é Dene First Nation et al., 2001); stone lanceolates (arrowheads used for killing caribou) found in the Artillery Lake area have been dated back to 3000 BC (MacNeish, 1951; Noble, 1971, 1981). Explorers traveling in the region over 200 years ago estimated the number of Dene in this area at the time of European contact to be between 2500 and 5000 (Mooney, 1928; Thompson, 1966). Explorers such as William Stewart (1715-17) and Samuel Hearne (176987) reported encountering camps of at least 700-1000 Dene in their travels. The communities of Dene and their caribou harvesting practices have changed significantly since European settlement, and the most significant changes have occurred in the last 100 years. Technology, including snowmobiles, radios, and air transport, now enables the Denésołıné to travel across the landscape and communicate with other communities with minimal time and effort. Nonetheless, many aspects of traditional caribou harvesting practices are still in use today, including the practice of observing caribou movements.

\section{METHODS}

This paper draws from the results of two interrelated traditional ecological knowledge projects carried out between 1997 and 2000 with the Lutsël K'é Dene First Nation (Lutsël K'é Dene First Nation et al., 1998; Parlee et al., 2001) and support from the West Kitikmeot Slave Study Society, a regional research funding agency (WKSS, 1995). Additional insights were gained from a third research project carried out in 2001, which focused on caribou movements around a proposed diamond mine (Lutsël K'é Dene First Nation et al., 2001). Terms and conditions for data collection, analysis, and reporting were set out in research agreements between the Lutsël K'é Dene First Nation Chief and Council, the researchers, and the funding agencies. The methodology was loosely based on the principles of participatory action research (PAR) (Friere, 1973); consideration was also given to adaptations of PAR developed by the Dene Cultural Institute and others involved in documenting Dene traditional knowledge (Bielawski and Lutsël K'é Dene First Nation, 1992; Johnson, 1992a, b; Ryan, 1995). Methods were developed to address specific project objectives and to meet the needs of the community. For example, all projects were guided by the Wildlife, Lands and Environment Committee and an elders' committee and included an onthe-land component during which elders and youth worked and learned together. Local personnel (community researchers) were the primary information gatherers for all projects and were also trained in database management and GIS mapping technology.

The community-based research effort for these projects was complex and substantial. Data were collected in semidirected interviews with individuals and small groups of Denésołıné elders and harvesters (27 in the first project, Łutsël K'é Dene First Nation et al., 1998), and 51 in the second (Parlee et al., 2001). Audio or video recordings (or both) were made of each interview and verified by community researchers, using translators, during on-the-land workshops with elders and caribou harvesters. Data collection on 1:250 000 and 1:50 000 scale maps was also undertaken, and these data were integrated into the local geographic information system. Stories shared during small-group interviews and elders' meetings were also recorded. Results include a wide range and depth of local and traditional knowledge about the Dene way of life. Only information relating to caribou health, habitat, and migration and harvesting strategies is presented in this paper. Evelyn Marlowe, Wally Desjarlais, Marcel Basil, and Nancy Drybones were the primary community researchers, and Bertha Catholique was the primary translator involved in the projects. Consent forms were also completed with individual interviewees whose knowledge, including direct quotations, formed the basis of this paper. Both the overall argument of the paper and specific details about hunter organization and caribou health were discussed and verified by the Lutsël K'é Dene First Nation's Wildlife, Lands and Environment Committee and the elders during meetings in 2003 and 2004.

\section{RESULTS: TRADITIONAL DENÉSOŁINÉ MONITORING OF CARIBOU MOVEMENTS}

The elders interviewed shared their memories of hunting practices in the past. Traditionally, the Denésołıné would begin to get ready for the fall harvest at family camps established along the north shore of Great Slave Lake (Fig. 2). According to Denésołıné elders, there were camps in all the small bays and inlets where the fishing was good and moose were likely to be sighted. It was in these camps that families would organize themselves into hunting parties. The hunters themselves would generally be male members of extended family groups: grandfathers, fathers, and sons would work together. Wives, aunts, mothers, and daughters were also involved in the hunt, sewing garments and hunting bags and preparing packets of dry fish and berries for those traveling. Denésołıné women were also recognized as skilled hunters (Judith Catholique, 18 June 1997). Families that were unable to 


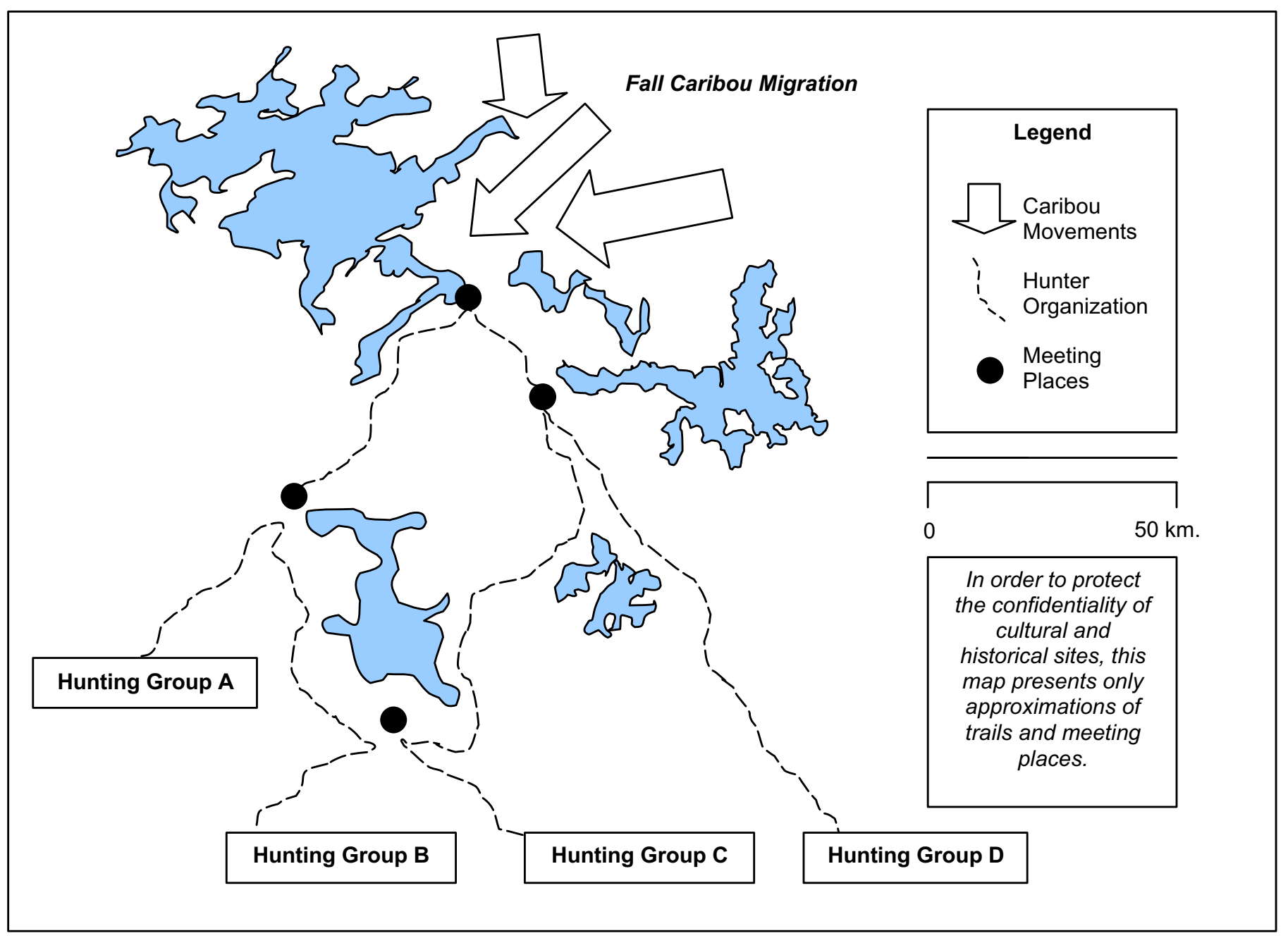

FIG. 3. Hunter organization across the landscape.

hunt would give what they could in anticipation of sharing in the harvest.

In the beginning, the elders say, the hunters would split up and go in every direction on foot. Some of the hunting parties would move north or northwest to McKay Lake. Others would move in a north or northeasterly direction toward Aylmer Lake, the Lockhart River, and Artillery Lake.

Although countless trails seem to extend into the barren lands, the elders say that the Denésołıné traditionally followed four main routes: Tath a Deze, Des Delgahi Deze, Des Tsel Che Deze, and Desnethche (Parlee et al., 2001) (Fig. 2). These travel routes, followed by many generations of Denésołıné, are still in use. Evidence of this history is visible in the graveyards, trail markers, arrowheads, and campsites dotted along the paths and portages. Denésołıné place names and legends also indicate the long-lived relationship between the people and the landscape. One prominent figure in legends and place names is Hachoghe, a larger-than-life character who followed beavers of mythical size from Artillery Lake to Great Slave Lake. During the fall caribou hunt, these stories are told and retold by fathers and mothers to their children and grandchildren to guide them as they travel.

\section{Hunter Organization, Observation and Communication across the Landscape}

The elders said that organization of hunting parties, including their travel north of the tree line, was key to ensuring that hunters would be able to find caribou on the fall and winter ranges (Fig. 3). Hunters traveling into the barrens would periodically reconnect at familiar camps close to areas where caribou were known to have passed in previous years. Of particular significance were the small pockets of black spruce (Picea mariana) and the thickets of willow (Salix ssp.) and birch (Betula glandulosa, B. glandulifera) found in the valleys and along rivers in the barren lands ( $t s^{\prime} u$ dzaii) and near the tree line ( $t s^{\prime} u d z a$ $a z e$ ). The best $t s^{\prime} u d z a i i$ and tsu dza aze were those that were close to drinking water, offered both dry wood for fuel and strong green trees for setting camps, were relatively sheltered from weather, and were near some high land that could be used as a lookout. As they traveled 
through the barren lands, hunters would use such $t s^{\prime} u d z a i i$ as reference points or guides to find other hunting parties. These periodic meetings enabled hunters to share food as well as information about caribou movements. Signs or indications of approaching caribou, such as footprints, fecal pellets, and bushes thrashed by antlers, would be reported. If one or two caribou were taken, the group would share the harvest together and then travel even farther into the barren lands. Distances traveled by the hunters would vary significantly, depending on their capacity to move between hunting camps to communicate. Younger hunters might travel upwards of $20 \mathrm{~km}$ per day on foot, while others might travel less than $10 \mathrm{~km}$. Leadership was an important part of the organization and communication between the hunters. Leadership was generally visible among family groups. The eldest hunter from each extended family group would assume the responsibility of leading each hunting party and, when the time came, for distributing meat. Sometimes, however, there was one individual who, because of age, past experience, or reputation as a successful hunter, would provide direction for many hunters.

As hunters came within sight of the crossings, they would watch for signs of caribou coming, gathering together, or regrouping depending on indications of their direction. Sighting of a few caribou approaching from the east or west was indication enough for parties to move in that direction.

Landscape features played an important role in the distribution of the hunters within the range. Like the caribou, hunters would travel along lake shorelines, eskers, and other heights of land. Use of these landscape features not only made travel in the barrens easier for hunters, but also increased the likelihood of their encountering caribou. The narrows of the big lakes, or eda, were key areas where the Denésołıné knew they could find caribou. Among the most significant caribou crossings were those on McKay Lake, Aylmer Lake, and Artillery Lake. These lakes are known as "the big water": Tha K'ai Tué, Tla Kai Tué, and Edacho Tué. They stretch over $300 \mathrm{~km}$ from west to east across the landscape (Fig. 1).

At their widest points, however, McKay Lake, Aylmer Lake, and Artillery Lake form a barrier to the fall migration. Although caribou are good swimmers and their dense coats provide them with buoyancy, they will travel along the shoreline until they can find a narrow point or crossing (eda). There the animals can easily cross in minutes or seconds (Fig. 4).

The elders said the most important crossings would be well marked by caribou trails from previous years; there the hunters would find strategic places to watch for the caribou. These "waiting places" $\left(k^{\prime} a\right)$ were usually on heights of land with a good view of the crossings. Large boulders or erratics on these hills made good waiting places for hunters: they could stay hidden for hours, watching and listening for sight or sound of caribou on the horizon or observations from other hunters that the caribou were nearing.
Hunters would not always depend on natural erratics for caribou blinds. In some areas, they would devise their own hiding places from smaller rocks. At a distance, these $k^{\prime} a$ appear similar to other boulders dotting the hills. Upon inspection, however, it is easy to see the care taken in their engineering and construction. From these locations, the hunters would be able to assess the health of the herd, as well as observing the direction of its movement.

\section{Observations of Caribou Movements and Condition: Anticipation of the Winter Range}

Hunters would also observe many health-related indicators, including size and composition of the groups, rate and direction of movements, behaviour, and body condition, to decide which groups to follow to their winter range and which animals to harvest. If the caribou crossed around McKay Lake, the caribou were more likely to winter in the western part of the winter range. If they used the eastern crossings, hunters knew they could be found closer to Artillery Lake and Łutsël K'é, in the eastern part of the winter range.

The water crossings were not the only landscape features the hunters recognized as important in understanding caribou movements; other features, including the shape and condition of the land around the crossing, also factored into their understanding of local caribou movements. Some elders said that caribou were more likely to travel on thai nene (flat land), sheth (hills), or thai t'ath (eskers) and less likely to travel on very rocky areas (na yaghe), rough hummocky land (ni horelghus nene) or very wet areas (elel). However, hunters were most confident they would find caribou by locating areas where there was good "food" (reindeer lichen, Cladina spp.), and by avoiding areas spoiled by fire. In some key areas, these features would function together, much like a funnel, drawing the caribou together toward the narrows of the lakes. The first few caribou would cross tentatively; the others would follow more certainly, in one long stream, until all were safely on the other side.

The caribou would begin to return to the Denésołıné at the end of the summer. The bulls would be the first to appear around McKay and Aylmer lakes, fattened from the summer feeding and ready for the rut (ek'enalde). By early fall, the old bulls (betsicho) would stand out clearly, with their fully developed sets of antlers heavy at the brow and bright red from shedding velvet (etthen erel ch'al). The antlers of the younger bulls (yalaghus) would be smaller and their behaviour more jittery, like that of teenagers. They would follow alongside the older males. The sighting of these few bulls would be a sign to the hunters that the large herd of cows and younger caribou was not far behind. The cows would travel more slowly, staying near their calves and the other young caribou to show them the route to the winter range. By this time, the cows too would have developed a large set of antlers and a thick coat for the winter season. After a summer of nursing and protecting their calves, they would be skinnier than the bulls. Some 

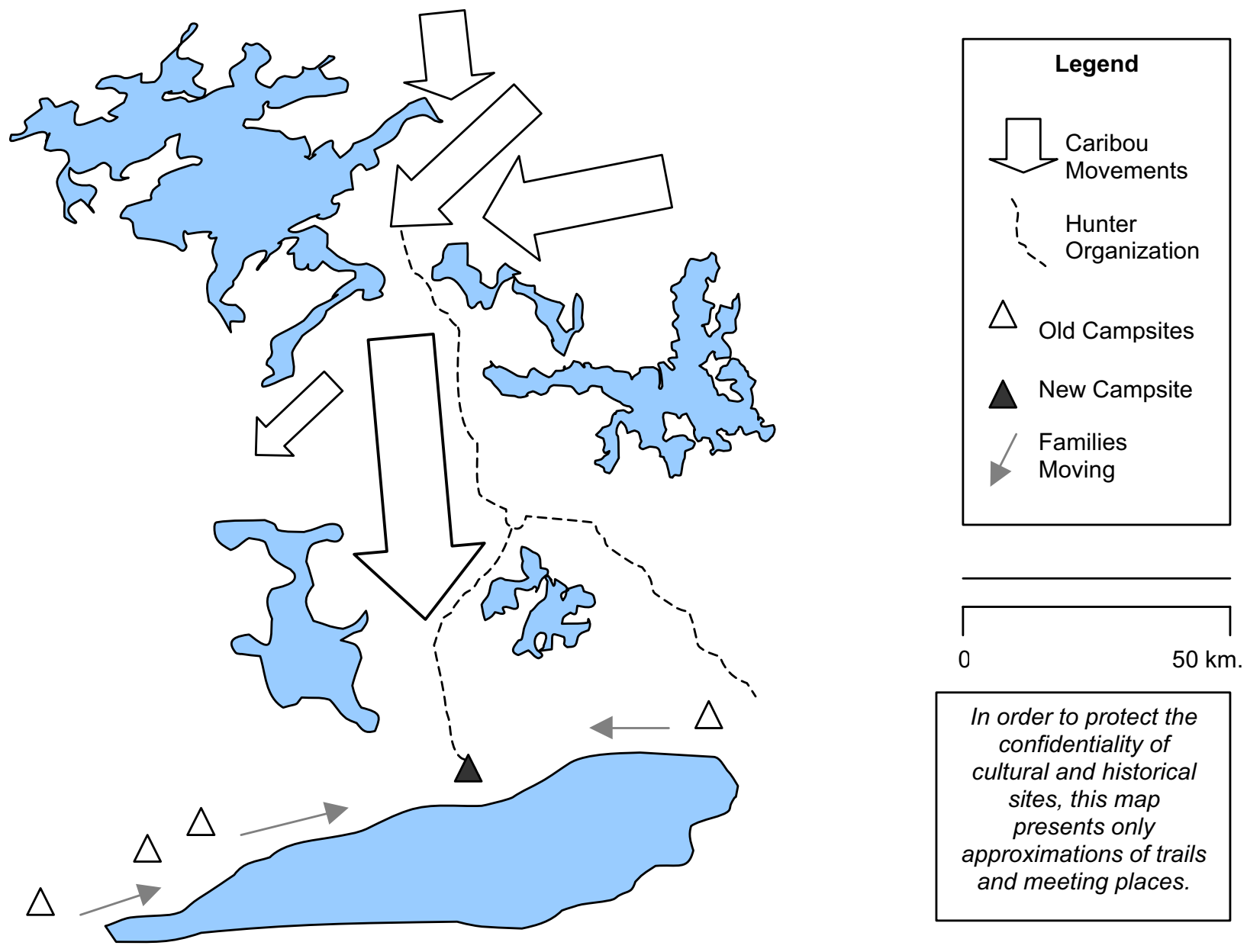
In order to protect the confidentiality of cultural and historical sites, this map presents only approximations of trails and meeting places.

FIG. 4. Relocation of family camps.

might have lost their calves early because of harsh winter or late spring. Other cows might have lost their calves to wolves or other predators. All calfless cows traveled alone. Body condition, a key indicator of herd health, was known to change significantly from year to year. Some years were known for more numerous insects, which would irritate and stress the caribou, sometimes to the point where they would stop eating and consequently become skinny. In some years, hunters would notice fewer fat caribou coming from the west (Bathurst herd) than from the east (Beverly herd). The Denésołıné hunters, waiting at the crossings, would watch all these signs to decide which animals to harvest.

If there were many bulls, the hunters would choose from the fattest among them, recognizing the fat animals by indicators such as a wide chest and a tail hidden in the welldeveloped hindquarter. A "busy" set of antlers (with many branches) and a well-developed coat were also indicators to the hunters that the animal was healthy. According to one elder interviewed, ensuring the animal was fat was an important part of the harvest:
Good-looking caribou - their horns look nice and their fur is pretty white. By that you know the caribou is fat... during the [late] fall you don't shoot the male caribou because they are skinny. They don't eat at that time because [of the rut] — they are chasing the female caribou.... When you shoot a caribou, the first thing you do is check if the caribou is fat by cutting in the middle of the stomach. If the caribou is fat, the hunter is happy. (J.B. Rabesca, 15 October 1998)

As the caribou approached the crossings, the hunters would take advantage of the opportunity to harvest the early bulls. Once the rut began, the bulls would not only be too thin to harvest, but they would have a strong smell and taste that is unpalatable (etsen). Now, however, the fresh meat and rich fat would be a welcome prize after weeks of dried fish and berries. The hunters would set a campfire or a temporary camp to share the "goodies" - tongue, liver, kidneys and back fat. The hunters would not rest long; they would be anxious to find enough meat to feed their families through the winter. After eating and packing a bit of the meat, the hunters would cache the remainder under- 
ground or in a rock crevice and mark it clearly so that others behind them would also be able to take advantage of the early harvest.

\section{Relocation of Family Camps}

Once the hunting parties found the large migration, news of the direction of the herd as well as small stores of fresh meat would be delivered back to waiting families. The capacity of families to learn and adapt to the movements of the caribou clearly depended on the hunters' being successful in their organization to observe and communicate caribou movements. When the caribou were coming, it was a very exciting time:

When the caribou were coming, you could see them on the lake - on the narrows. Guns would fire and everyone was happy. People would yell, "Yahoo!" Even the old ladies would howl "Yahoo! Yahoo!" (Noel Drybones, 9 July 1997)

Depending on what was reported to them, families would prepare themselves for the harvest in their existing camps or would relocate farther east or west to join other families (Fig. 4). Some families might move camps $100 \mathrm{~km}$ or more. Eventually many families would be congregated together near the area where caribou were most likely to pass and overwinter. If they were successful in locating the winter range, families might not have to move again for many months.

Camps could not be located too far from the tree line (Fig. 2), as treed areas provided the firewood needed to prepare, dry, and store the meat for winter. Nor could the camps be located too far from areas where hunters predicted they would harvest a large number of caribou, since caribou meat is heavy to haul over long distances. If the meat were left for too long, it could also spoil or be ransacked by wolverines, wolves, or bears. The most effective harvesting strategy involved relocating camps along the tree line close to areas where large numbers of caribou were likely to overwinter.

Women played a key role in moving the family and ensuring that young children and elders were cared for. If meat or fish were in short supply, women would also have to hunt, sometimes taking caribou before the men arrived with the harvest. Hunters and their families developed systems and signals for how, when, and where to move camps; women would watch for tree branches pointing in a particular direction, or erratics with fresh sets of caribou antlers.

As the meat was harvested, it would be hauled back to the camp. The most valued parts of the caribou were the fat and organ meats, as well as the brain, thighs, arms, brisket, backbone, ribs, neck, backstrap, and hide. The backstrap and thighs were particularly valuable, as they were easiest to make into dry meat.

People traveled many tens and sometimes hundreds of kilometres to these gathering sites, which tended to be located in areas where the large migration had occurred in previous years. Camps near the crossings were traditionally large, according to the elders, sometimes numbering more than 1000 people. Tents could be seen everywhere. People would not camp right at the caribou crossing. Instead, they would set up tents, and later cabins, some distance away. The crossing itself was considered a sacred area by the Denésołıné and as such was protected and carefully watched. Everyone would be careful not to show arrogance towards the area and would conscientiously offer prayers, tobacco, matches, or other small items at the crossing. These gifts were given out of respect for the Creator, a sign of reciprocity for the gift of coming caribou.

The southern crossing of Artillery Lake was one such area where families commonly gathered. Aptly named edacho tué (the lake of the big caribou crossing), this was a place where people knew large numbers of caribou would pass each fall. Some families would stay there only in the fall for the caribou harvest and then would move on to trap in other areas of the barren lands or portage back to Tue Nedhe. For others, however, the security associated with the crossing was so great that they began to stay there all year round. In the early 1900 s, many people built cabins on Artillery Lake at the place just north of Timber Bay, and from time to time would stay there year-round.

As the harvest continued, more families would arrive and gather together. Fresh meat would be shared amongst everyone in the camp. Meat would also be dried and cached for the winter. If the harvest was very successful, enough meat could be cached to last until the following season. Caching meat was one way that the Denésołıné could ensure that they would have food during times when hunters were unable to harvest because of poor weather. The late elder Zepp Casaway described how caches were built in the barren lands:

\begin{abstract}
When the caribou are spotted, they are killed then brought to where there are some small trees. Trees are put on it or they can also be put under the ground for use in late winter and nothing can be taken. The wolverine is a real thief and this is done to prevent him from taking anything...Some of the meat would be cached under the moss and it freezes there. Small trees would be cut down to mark the spot because of the severe winter with its blizzards and bad weather. Only when it was a nice day, the people would go hunting. (27 September 1999)
\end{abstract}

\section{Dealing with Extreme Events: \\ The Importance of Denésołıné Spirituality}

Denésołıné understanding of caribou movements not only involved learning and adapting to physical signs; the Denésołıné also recognized spiritual beliefs as key to harvesting and surviving on the land. Some of these beliefs begin with a perspective of the caribou as spiritual beings and their migration as a spiritual journey. Some elders say 
that the cracks and fissures on some caribou skulls tell the migration story of each caribou. Parry Falls on the Lockhart River (Fig. 2), known to the Denésołıné as Tsankui Theda ('the old lady of the falls'), also provided spiritual guidance about caribou movements. As Maurice Lockhart ( 8 August 2000) explained, steam rising from the falls during colder months provided the hunters with guidance about where to hunt. "[The steam], it bends... whichever way it points, that is where the caribou are. The people go that way to find the caribou."

Such spiritual beliefs were particularly important to the Denésołıné during years when there were very few caribou. Many Denésołıné elders attribute the absence of caribou in some years to a lack of respect shown for the land and animals; they believe that people must respect the caribou or they will not come back to them. That respect is demonstrated in many ways. Good hunting practices and proper harvesting and preservation of meat are some ways to demonstrate this respect (J.B. Rabesca, 15 October 1998). There were also certain codes of respect for men and others for women. Madelaine Drybones (9 June 1999) described how the men showed respect when hunting:

The men would cut off the pointed part of the heart and throw it away right there and then. Also they cut off the tip of the caribou tongue to show respect for the caribou. They would work on cutting up the meat themselves and make sure no one stepped over the caribou leg. They would leave the pile of bones in one place and leave it there.

Using all parts of the caribou and wasting nothing was also an important form of respect. "In the olden days, they didn't even throw away caribou bones. They used the bones for fat. They would break up the bones into small pieces and then boil them in water. Everything was kept from the caribou" (Liza Enzoe and Mary Rose Enzoe, 16 October 1998). An important part of the Denésołıné women's work was drying meat to preserve it and ensure nothing was wasted.

Chasing or hitting the caribou has always been a strong sign of disrespect, which the Denésołıné believe results in unexpected and unwanted changes in caribou migration. "Once someone [hits the caribou], the caribou will [migrate] further out and that is very bad for the people" (Noel Michel, 4 October 1999). Within the context of caribou harvesting, these demonstrations of respect are also a means of further limiting the uncertainty associated with caribou movements by limiting the impact of small-scale human disturbance.

\section{Effects of Development on Caribou Movements}

Large-scale human disturbances, such as forest fires and mining projects, have added a new dimension to the variability of caribou movements. Although small fires are recognized as a natural occurrence, the size and frequency of forest fires in recent years are of great concern to elders, who worry about the impact on caribou and caribou migration in the area:

Regarding the forest fires, some scientists say it's good for new growth. But do you know what the caribou eat? If the lichen burns, it will take over 100 years for the plants to grow back. Some scientists say these forest fires are good, but it's not like that for us. There never used to be so many forest fires. I have never before seen a forest fire started by lightning. We look after the land and we respect the land and the animals. (Pierre Marlowe, 6 November 2000)

The reason why there is less caribou now is because of the forest fires in the area. Caribou vegetation is all burnt around Nanacho Lake (Nanula Tué). On the north side of McLeod Bay (Tue Nedhe) it is also burnt. The south side is not so burnt. Caribou come to the south side because of that. We can't do anything about what has happened with these fires. We cannot help what happened, nor could we have stopped it. The land has to grow back by itself. It's all a part of Mother Nature's life. (Alice Michel, 18 October 2000)

The potential impacts of resource development have been a key concern for the Denésołıné since the early 1900s, when a gold mine was developed near Yellowknife. More recently, diamond exploration and mining projects (such as BHP Billiton Diamonds Inc's Ekati Diamond Mine and the Diavik Diamond Mine at Lac de Gras and DeBeers' Snap Lake Diamond Mine) have raised community concern (Fig. 2). The late elder Louis Abel (17 June 2001) predicted that such development would likely be the source of significant change in the size of the groups migrating and their routes:

In a few years, the caribou will change their route again. They will go a different way; they will be disturbed by the winter road, planes, and blasting. You will see [these changes] in three to five years from now.

Roads are of particular concern to elders, who perceive them as unnatural barriers to caribou movement. Currently a $500 \mathrm{~km}$ winter road (seasonal road rebuilt every year) links diamond mines at Lac de Gras to Yellowknife and points south, and a series of all-weather roads have been constructed within the footprint of the mine. Some elders are particularly concerned about Misery Road, a stretch of all-weather road running northwest to southeast that connects a new diamond pit with the processing plant. This road stretches more than $29 \mathrm{~km}$ across known caribou spring and summer migration paths. "The road is like a corral or wall, blocking the caribou from moving west through the area," said Ernest Boucher (17 June 2001). The elders' interpretation that the roads are blockages to caribou movements is based on their observation of how the all-weather roads are constructed. The roads are 
elevated $1 \mathrm{~m}$ or more above ground level, with raised shoulders constructed of large rocks; in the elders' view, it would be difficult for caribou to cross without injuring themselves. Although some pathways (or ramps) have been engineered so that the caribou can cross, elder J.B. Rabesca (14 February 2001) argues that these relatively small openings are insufficient for the large number of caribou that traditionally pass through the area:

\begin{abstract}
Regarding the winter road, if you make a road, you cannot make it too high. It's too hard for the caribou to get over it. It should be lower. The caribou won't just pass through a little pathway you make, they go all over. The road needs to be fixed.
\end{abstract}

This perception of the roads as barriers to caribou movement is arguably based on the elders' past experiences and observations of caribou movements around natural landscape features. These new roads are not interpreted as good for the caribou; elders worry that the increasing number of mines and roads in the region may eventually stop the return of the caribou (etthen niltla):

No matter what you do, caribou will be affected by these mines and roads. The only way to not affect the caribou is to have no mines and roads. If there is a mine, there will be roads. And if you have a road, there will be trucks on it. If they put it through, you can't stop everything for the caribou. But maybe that is what the caribou need. (Pierre Catholique, 11 July 2001)

\section{DISCUSSION AND CONCLUSION}

The importance of the caribou to the Denésołıné is well established (Jenness, 1956; Gillespie, 1976; Jarvenpa, 1976; Smith, 1976, 1978, 1981; Sharp, 1977; Irimoto, 1981; Jarvenpa and Brumbach, 1988; Smith, 1998); caribou and harvesting has always been central to the social and cultural well-being of Denésołıné communities, tying extended families together with the land in traditional activities that date back many generations. Like other indigenous peoples with a strong relationship to the land, the Denésołıné have developed different ways of learning and adapting to variability in the abundance and distribution of resources in their environment. The research presented here describes how the Denésołıné traditionally dealt with variability in the fall migration of the caribou by organizing to observe and communicate about movements at key water crossings in the caribou's vast fall and winter range. The approach can arguably be described as a sophisticated system of monitoring-or as understood in Łutsël K'é, of watching, listening, and learning-to understand and adapt to ecological change.

Opportunities for involving aboriginal people and traditional knowledge in the monitoring and management of barren-ground caribou have grown in recent years, particularly in the face of concerns about climate change and nonrenewable resource development. In designing and developing these new monitoring approaches, significant focus and energy have been placed on finding indicators that are based on traditional knowledge. Caribou body fat (back fat, stomach fat, marrow) is an indicator of health used by many northern hunters, including the Gwich'in in the Yukon (Kofinas et al., 2002; Lyver and Gunn, 2004). There is evidence that a number of indigenous groups, from Labrador to Alaska, monitor the fat content of caribou in ways that make it possible to assess the status of the herd and to predict trends (Berkes, 1999). All of these indicators, while technically relevant, originated in a specific social, cultural, and ecological context. Once they are detached from that context, there is the potential for misuse and misinterpretation; the social and cultural values associated with the monitoring of such indicators may also be lost.

This research suggests that the inclusion of traditional knowledge in caribou monitoring need not be limited to indicators. Denésołıné and other indigenous peoples have their own approaches to monitoring, including ways of organizing as families and communities and methods of empirical observation, interpretation, and communication. The value and reliability of this system, as well as its sustainability, have been tested and retested by hunters and their families for generations, as evidenced by the continuance of caribou harvesting as part of the Denésołıné way of life.

The Denésołıné strategy of organizing and observing movements at key water-crossing points in the caribou range provides opportunities to learn about a whole range of other ecological parameters or indicators of the land. The information captured at those crossing points goes beyond basic movement data; it carries multiple population indices based on the timing of the migration, the size and composition of the groups, the physical condition of the animals, and their direction and rate of travel. Together, these observations provide an integrative and holistic perspective on the parameters affecting population health, a perspective that could complement information obtained from satellite telemetry and population surveys.

There is also much to be learned from the Denésołıné about how to deal with complexity and uncertainty. Living with uncertainty is one of the key survival skills for societies in an era of rapid change and unpredictability (Berkes et al., 2003). As initially suggested by Smith (1978), the Denésołıné have in fact developed a highly sophisticated and locally adapted monitoring system to deal with the variability in caribou movements. Traditional Denésołıné monitoring has the elements of feedback learning and adaptive management (Berkes et al., 2000). It is highly resilient; as a hunting system, it is able to absorb year-to-year changes in caribou movements; and it shows the people's ability for self-organization and capacity to learn and adapt (Berkes and Folke, 2002). While there are challenges in using traditional knowledge to solve problems in resource management (Lyver and Gunn, 
2004; Ellis, 2005), systems like traditional Denésǫłné caribou monitoring can play a role in helping communities reduce their own uncertainty about rapid social, cultural, and ecological change. Elders and leaders may feel significantly reassured by having members of their own community involved in monitoring caribou health. The benefits of involving community members can increase exponentially when monitoring is based on traditional knowledge and practices that are fundamental to the way of life of the community.

\section{ACKNOWLEDGEMENTS}

This paper is dedicated to the elders of Łutsël K'é Dene First Nation, with special remembrances of the elders who passed on during the course of our research. Special thanks also go to those community members who have invested their time and energy in the research: Evelyn Marlowe, Wally Desjarlais, Terri Enzoe, Walter Desjarlais, Marcel Basil, Nancy Drybones, Shawn Catholique, Jeanette Lockhart, Agatha Marlowe, Dennis Drygeese, Marie Catholique, Gloria Enzoe, Charlie Catholique, August Enzoe, Florence Catholique, Bertha Catholique, James Marlowe, Stan Desjarlais, Lawrence Catholique, Chief Archie Catholique, Ellen Bielawski, Anne Kendrick, Phil Lyver, and Steve Ellis. The guidance of Dr. Fikret Berkes and the support of the Natural Resources Institute, University of Manitoba, and the Northern Scientific Training Program are also greatly appreciated.

\section{REFERENCES}

BERKES, F. 1999. Sacred ecology: Traditional ecological knowledge and resource management. Philadelphia: Taylor and Francis.

BERKES, F., and FOLKE, C. 2002. Back to the future: Ecosystem dynamics and local knowledge. In: Gunderson, L., and Holling, C.S., eds. Panarchy: Understanding transformations in human and natural systems. Washington, D.C.: Island Press. 121-146.

BERKES, F., COLDING, J., and FOLKE, C. 2000. Rediscovery of traditional ecological knowledge as adaptive management. Ecological Applications 10(5):1251-1262.

- 2003. Navigating social-ecological systems: Building resilience for complexity and change. Cambridge: Cambridge University Press.

BIELAWSKI, E., and the ŁUTSËL K'É DENE FIRST NATION. 1992. The desecration of Nanula Tue: Impact of the Talston hydroelectric project on the Dene Soline. Ottawa: Royal Commission on Aboriginal Peoples.

CAMERON, R.D., REED, D.J., DAU, J.R., and SMITH, W.T. 1992. Redistribution of calving caribou in response to oil field development on the arctic slope of Alaska. Arctic 45(4): $338-342$.

CAMERON, R.D., LENART, E., REED, D., WHITTEN, K., and SMITH, W. 1995. Abundance and movements of caribou in an oilfield complex near Prudhoe Bay, Alaska. Rangifer 15(1): $3-7$.
DOGRIB TREATY 11 COUNCIL. 2001. Dogrib traditional knowledge: Relationship between caribou migration patterns and the state of caribou habitat. Yellowknife: West Kitikmeot Slave Study Society. http://www.wkss.nt.ca./HTML/08_ProjectsReports/ 08_caribou/08_dogribTKRelation.htm. Accessed 2 June 2004.

ELLIS, S.C. 2005. Meaningul consideration? A review of traditional knowledge in environmental decision making. Arctic 58(1): $66-77$.

FRIERE, P. 1973. Education for critical consciousness. New York: Seabury Press.

FRYXELL, J.M., and SINCLAIR, A.R. 1998. Causes and consequences of migration by large herbivores. Trends in Ecology and Evolution 3:237-241.

GILLESPIE, B.C. 1976. Changes in territory and technology of the Chipewyan. Arctic Anthropology 13(1):6-11.

GUNN, A., DRAGON, J., and BOULANGER, J. 2001. Seasonal movements of satellite-collared caribou from the Bathurst herd: Final report to the West Kitikmeot Slave Study Society. http:// www.wkss.nt.ca/HTML/08_ProjectsReports/PDF/Seasonal MovementsFinal.pdf. Accessed October 2004.

IRIMOTO, T. 1981. The Chipewyan caribou hunting system. Arctic Anthropology 18(1):44-56.

JARVENPA, R. 1976. Spatial and ecological factors in the annual economic cycle of the English River Band of Chipewyan. Arctic Anthropology 13(1):43-69.

JARVENPA, R., and BRUMBACH, H.J. 1988. Socio-spatial organization and decision-making processes: Observations from the Chipewyan. American Anthropology 90(3):598-615.

JENNESS, D. 1956. The Chipewyan Indians: An account by an early explorer. Anthropologica 3:15-33.

JOHNSON, M. 1992a. Dene traditional knowledge. Northern Perspectives 20(1):2.

— Documenting Dene traditional knowledge. Akwe'kon Journal (Ithaca) 9(2).

KOFINAS, G., with the COMMUNITIES of AKLAVIK, ARCTIC VILLAGE, OLD CROW, and FORT McPHERSON. 2002. Community contributions to ecological monitoring: Knowledge co-production in the U.S. - Canada borderlands. In: Krupnik, I., and Jolly, D., eds. The earth is faster now: Indigenous observations of Arctic environmental change. Fairbanks: Arctic Research Consortium of the United States. 54-91.

ŁUTSËL K'É DENE FIRST NATION, PARLEE, B., and MARLOWE, E. 1998. Traditional knowledge of community health: Final report. Yellowknife: West Kitikmeot Slave Study Society. http://www.wkss.nt.ca/HTML/08_ProjectsReports/ PDF/TkofCommunityHealthFinal.pdf. Accessed 2 June 2004.

ŁUTSËL K'É DENE FIRST NATION, ELLIS, S., PARLEE, B., CATHOLIQUE, B., CATHOLIQUE, H., MICHEL, M., and CATHOLIQUE, S. 2001. Traditional knowledge in the $\mathrm{Na}$ Yaghe Kué region: An assessment of the Snap Lake Project. Yellowknife: De Beers Canada Mining Inc., Mackenzie Valley Environmental Impact Review Board. Available from Łutsël K'é Dene First Nation, Wildlife, Lands and Environment Committee Office, Box 28, Łutsël K'é, Northwest Territories X0E1A0; wildlife@lutselke.com.60 p. 
LYVER, P.O'B., and GUNN, A. 2004. Calibration of hunters' impressions with female caribou body condition indices to predict probability of pregnancy. Arctic 57(3):233-241.

MacNEISH, R.S. 1951. An archaeological reconnaissance in the Northwest Territories. Annual Report for 1949-50. National Museum of Canada Bulletin 123:24-41.

MANSEAU, M., HUOT, J., and CRÊTE, M. 1996. Effects of summer grazing by caribou on composition and productivity of vegetation: Community and landscape level. Journal of Ecology 84:503-513.

MESSIER, F.J., HUOT, J., LE HENAFF, D., and LUTTICH, S. 1988. Demography of the George River Canada caribou herd: Evidence of population regulation by forage exploitation and range expansion. Arctic 41(4):279-287.

MOONEY, J. 1928. The Aboriginal population of America north of Mexico. Smithsonian Miscellaneous Collections 80(7).

NOBLE, W.C. 1971. Archaeological surveys and sequences in central district Mackenzie, N.W.T. Arctic Anthropology 8(1):102-135.

1981. Prehistory of the Great Slave Lake and Great Bear Lake region. In: Helm, J., ed. Handbook of the North American Indians, Vol. 6: Subarctic. Washington, D.C.: Smithsonian Institution. 97-106.

PARLEE, B., BASIL, N., and DRYBONES, N. 2001. Traditional ecological knowledge in the Kaché Tué study region: Final report. Yellowknife: West Kitikmeot Slave Study. http:// www.wkss.nt.ca/HTML/08_ProjectsReports/08_final/ 08_finalreport.htm. Accessed 2 June 2004.

PARLEE, B., MANSEAU, M., and the ŁUTSËL K'É DENE FIRST NATION. 2005. Understanding and communicating about ecological change: Denésołıné indicators of ecosystem health. In: Berkes, F., Huebert, R., Fast, H., Manseau, M., and
Diduck, L., eds. Breaking ice: Renewable resource and ocean management in the Canadian North. Calgary: University of Calgary Press. 167-184.

RESOURCES, WILDLIFE AND ECONOMIC DEVELOPMENT. 2004. Barren-ground caribou distribution. (Map of caribou herd annual ranges based on satellite-collared cows.) Yellowknife: Government of the Northwest Territories. http://www. nwtwildlife.rwed.gov.nt.ca/NWTwildlife/caribou/ distribution.htm. Accessed 12 January 2005.

RYAN, J. 1995. Doing things the right way. Calgary: University of Calgary Press.

SHARP, H.S. 1977. The Caribou Eater Chipewyan: Bilaterality, strategies of caribou hunting, and the fur trade. Arctic Anthropology 14(2):35-40.

SMITH, D.M. 1998. An Athapaskan way of knowing: Chipewyan ontology. American Ethnologist 25(3):412-432.

SMITH, J.G.E. 1976. Local band organization of the Caribou Eater Chipewyan. Arctic Anthropology 13(1):12-24.

- 1978. Economic uncertainty in an "original affluent society": Caribou and Caribou Eater Chipewyan adaptive strategies. Arctic Anthropology 15(1):68-88.

- 1981. Chipewyan. In: Helm, J., ed. Handbook of the North American Indians, Vol. 6: Subarctic. Washington, D.C.: Smithsonian Institution. 271-284.

THOMPSON, H.P. 1966. A technique using anthropological and biological data. Current Anthropology 7(4):417-424.

WKSS (WEST KITIKMEOT SLAVE STUDY). 1995. Terms of Reference. Yellowknife: WKSS. http://www.wkss.nt.ca/HTML/ 03_Terms/03_index.htm. Accessed 2 June 2004.

WOLFE, S.A., GRIFFITH, B., and GRAY WOLFE, C.A. 2000. Response of reindeer and caribou to human activities. Polar Research 19:1-11. 